\title{
Skaergaard Intrusion, East Greenland: contact metamorphism and deformation on Mellemø
}

\author{
JOHN S. MYERS
}

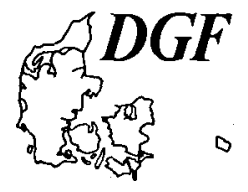

\begin{abstract}
Myers, J. S.: Skaergaard Intrusion, East Greenland: contact metamorphism and deformation on Mellemø. Bull. geol. Soc. Denmark, vol. 28, pp. 1-4, Copenhagen. October 23rd, 1979.

https://doi.org/10.37570/bgsd-1979-28-01

Contact metamorphism and deformation are described from part of the Skaergaard intrusion. Rapid heating of the envelope was followed by relatively slow cooling. Deformation occurred in the contact zone after crystallization of the Chilled Marginal Gabbro; pelitic rocks are strongly deformed, folded and brecciated, and psammitic rocks are injected as partial melts into fracture zones in the gabbro.
\end{abstract}

John S. Myers, Geological Survey of Greenland, Oster Voldgade 10, 1350 Copenhagen, Denmark. November 28th, 1978.

The contact relations of the Skaergaard intrusion and its host rocks differ from place to place (Wager \& Deer 1939, p. 25-34). At most localities the contact is sharp and the contact zone is little deformed, but on Mellemo (fig. 1) where the intrusion is in contact with thin sedimentary rocks resting on gneiss (Wager 1934, p. 26; Wager \& Deer 1939, p. 13 \& 26), the host rocks are highly metamorphosed and show a complex history of deformation.

\section{Description of rocks and metamorphism}

\section{Archaean gneiss}

Three samples of gneiss from Mellemø together with four other samples from the Skaergaard region give $\mathrm{a} \mathrm{Pb} / \mathrm{Pb}$ isochron with an age of $2980 \pm$ 20 m.y. (Leeman, Dasch \& Kays 1976). The petrography and chemical composition of the granodioritic gneiss on Mellemø are described by Wager \& Deer (1939, p. 10-12). They describe a sample of feldspar-quartz-biotite gneiss $150 \mathrm{~m}$ from the contact (Wager \& Deer 1939, p. 11 sample 1867) as unmetamorphosed by the Skaergaard intrusion except perhaps for the partial alteration of biotite to chlorite. However, a sample $1 \mathrm{~m}$ from the contact (Wager \& Deer 1939 , p. 12 sample 1870 ) is highly metamorphosed by the intrusion, with large, finely twinned plagioclase often seen to be enclosed by orthoclase and quartz. Hypersthene, green hornblende, biotite and opaque minerals are segregated into patches. $50 \mathrm{~cm}$ from the contact (GGU sample 230327), feldspars are intensely clouded and are patchily recrystallized, and pyroxenes are rimmed by green hornblende. Taylor \& Epstein (1963) analyzed the $0^{18} / \mathrm{o}^{16}$ ratios of a sample of gneiss from Mellemø (Wager \& Deer sample 1867) and rocks from the Skaergaard intrusion and suggested that water from the metamorphic aureole was locally absorbed by the gabbro magma.

Contact metamorphism is prominent up to about $20 \mathrm{~m}$ from the Skaergaard intrusion, and textures show that this metamorphism can be divided into two stages. An early stage of relatively anhydrous metamorphism in which hypersthene replaced Precambrian biotite was followed by a more hydrous stage in which pyroxene was rimmed by green hornblende, accompanied by the growth of epidote, clinozoisite, biotite and chlorite. The gneiss is cut by small fracture and shear zones associated with the emplacement of the Skaergaard intrusion. These deformation zoned formed during both early and late stages of recrystallization of the gneiss.

\section{Kangerdlugssuaq sedimentary series}

Pelitic hornfels. This is a finely layered, fine grained rock, with a macroscopic structure that resembles mylonite derived from quartozo-feldspathic gneiss, but on a microscopic scale is massive and consists of clusters of sillima- 


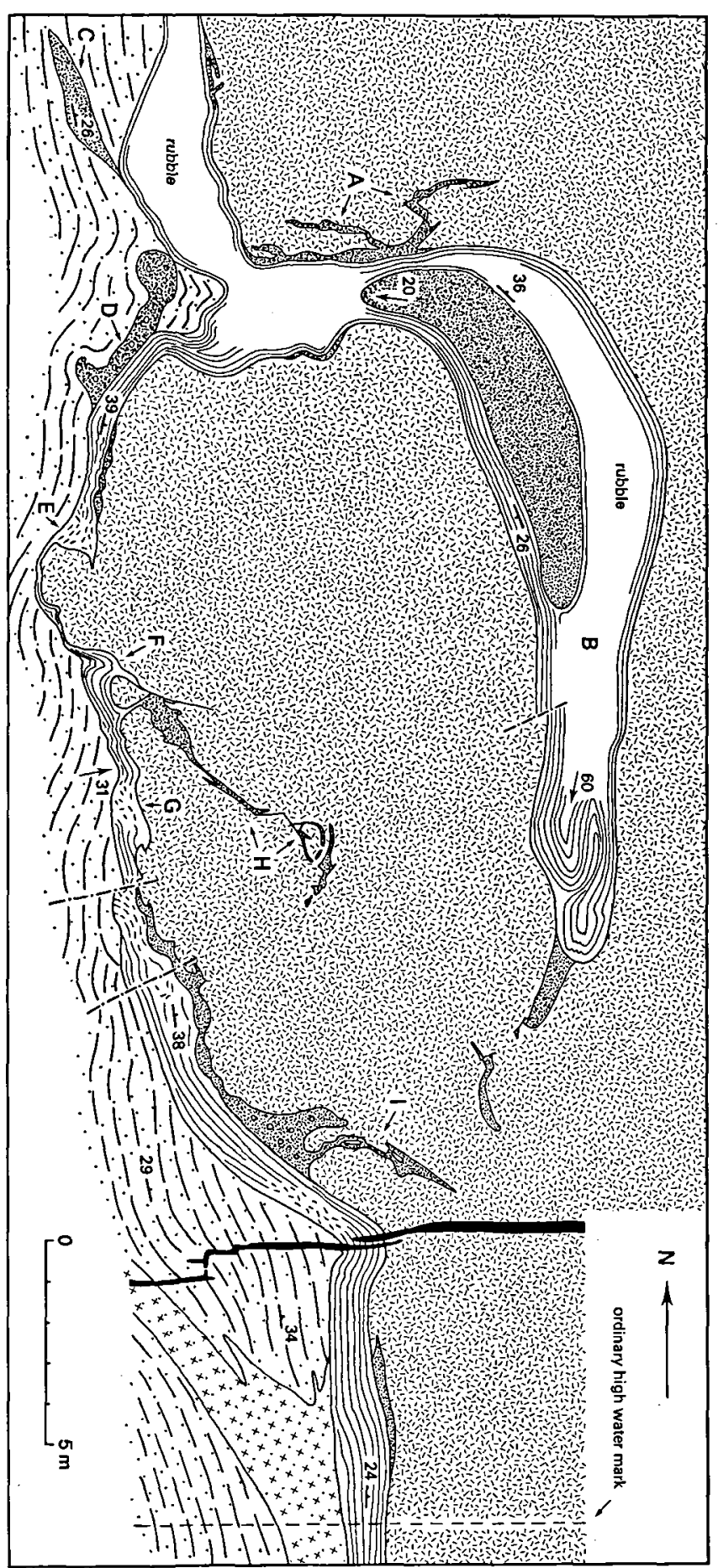


nite needles and poikilitic cordierite, with minor amounts of plagioclase, quartz, epidote and opaque minerals. Its composition suggests that it is a metamorphosed pelitic sedimentary rock as described by Wager $(1934$, p. 26$)$ and Wager \& Deer (1939, p. 13). The layering is marked by concentrations of opaque minerals, but it is not clear whether the layering is a primary sedimentary feature or a tectonic-metamorphic feature. This layering is shown on fig. 1, where it can be seen to be infolded with the gabbro. In some places the layering is attenuated and in some places it is fragmented (fig. 1, localities $E$ \& G), and set in a matrix of similar composition. These deformation features are overprinted by the contact metamorphic textures.

Psammitic hornfels. This occurs both below and above the pelitic hornfels. It is fine grained and mostly consists of rounded quartz grains with crenulate margins, and interstitial micas extensively altered to chlorite, poikilitic patches of cordierite, and minor amounts of sillimanite, green hornblende, and plagioclase partly altered to mica, chlorite and epidote. Quartzite pebbles occur in some places and comprise either highly strained quartz grains or fine grained, unstrained mosaics of quartz.

\section{Gabbro}

The gabbro shown on fig. 1 is the lowest part of the Chilled Marginal Gabbro unit of the Marginal Border Group described by Wager \& Deer (1939, p. 25-28) and Wager \& Brown (1968, p. 104-109). The gabbro shows a marked decrease in grain size towards the contact both on the scale of a few centimetres close to the contact, and on the scale of several metres. It is generally massive without any tectonic fabric, except for minor fracture and shear zones which cross both the gabbro and its host rocks.

\section{History of deformation and metamorphism}

The pelitic hornfels shows a sequence of ductile deformation followed by brittle deformation which was annealed by subsequent recrystallization. The texture of the quartzite pebbles in the psammitic hornfels record a history of deforma- tion and incomplete recrystallization, whereas the texture of the matrix shows more complete recrystallization.

Psammitic hornfels occurs both below the pelitic hornfels in the core of the anticline at $B$, and at $\mathrm{C}$ and $\mathrm{D}$ (fig. 1), and above the pelitic hornfels. This could be interpreted as either the original stratigraphic order, with two distinct units of psammitic hornfels, or a result of upward injection of some of the lower psammitic hornfels as a melt or partial melt through the pelitic hornfels after the intrusion of the gabbro.

The occurrence of psammitic hornfels as veins in brittle fractures within the gabbro (fig. 1, localities $\mathrm{A}, \mathrm{H} \& \mathrm{I}$ ) shows that the psammitic hornfels was at least partly melted and was injected into the gabbro during on episode of deformation after crystallization of the gabbro magma. The shapes of folds at $E$ and $F$ (fig. 1) show that the pelitic hornfels was more ductile than the gabbro when these folds developed.

These macroscopic structural features together with the metamorphic sequence seen under the microscope suggest the following sequence of events:

1. Brittle fracturing and intrusion of gabbro magma.

2. Rapid heating of the host rocks and growth of hypersthene in the gneisses within $20 \mathrm{~m}$ from the intrusion. The pelitic hornfels probably recrystallized from shale at this stage but no trace of this metamorphism has survived subsequent recrystallization. The psammitic hornfels was probably likewise recrystallized from sandstone and became partly molten.

3. The gabbro crystallized more rapidly than the pelitic and psammitic hornfels recrystallized, and this led to a ductility contrast between less ductile gabbro and more ductile hornfels. This resulted in folding of the gabbro/hornfels interface, ductile deformation within the pelitic and psammitic hornfels, and brittle fracturing of the gabbro. Some psammitic hornfels was injected along these brittle fractures as a melt or partial melt. In some parts of the pelitic hornfels ductile deformation was followed by brittle fracturing of the sedimentary or tectonic layering.

4. As the deformation waned or ceased, the temperature in the contact aureole was still high enough for the pelitic and psammitic hornfels to recrystallize with isotropic fabrics. In the adjacent 
gneiss, the circulation of hydrous fluids during slow cooling caused the partial alteration of pyroxene to hornblende, mica and chlorite.

Acknowledgements. The Skaergaard intrusion was visited during reconnaissance mapping of the coast between Kangerdlugssuaq and Angmagssalik in 1977 by the geological Survey of Greenland. Thanks are expressed to B. E. Gorman for assistance in the field. The manuscript is published with permission of the director of the Geological Survey of Greenland.

\section{Dansk sammendrag}

Kontaktmetamorfose og deformation beskrives fra en del af Skaergaard intrusionen. Hurtig ophedning af kontaktzonen blev efterfulgt af en relativt langsom afkøling. Deformation optræder $i$ kontakt zonen efter krystalliseringen af den Chilled Marginal Gabbro; pelitiske bjergarter er stærkt deformerede, foldede og breccierede, og psammitiske bjergarter er injicerede som partielle smeltemasser i brudzoner i gabbroen. Efter deformationens ophør forblev temperaturen høj nok til at de pelitiske og psammitiske bjergarter kunne rekrystallisere med hornfels struktur.

\section{References}

Leeman, W. P., Dasch, E. J. \& Kays, M. A. $1976:{ }^{207} \mathrm{~Pb} /{ }^{206} \mathrm{~Pb}$ whole-rock age of gneisses from the Kangerdlugssuaq area, eastern Greenland. Nature 263: 469-471.

Taylor, H. P. \& Epstein, S. 1963: $0^{18} / 0^{16}$ ratios in rocks and coexisting minerals of the Skaergaard intrusion, East Greenland. J. Petrol. 4: 51-74.

Wager, L. R. 1934: Geological investigations in East Greenland. Part 1, general geology from Angmagsalik to Kap Dalton. Meddr Gronland 105 (2): 1-46.

Wager, L. R. \& Brown, G. M. 1968: Layered igneous rocks. Edinburgh \& London: Oliver \& Boyd, 588 pp.

Wager, L. R. \& Deer, W. A. 1939: Geological investigations in East Greenland. Part 3, the petrology of the Skaergaard intrusion, Kangerdlugssuaq, East Greenland. Meddr Gronland 105 (4): 1-352. 